AGRITECH, Vol. 37, No. 4, November 2017, Hal. 437-442 DOI: http://doi.org/10.22146/agritech.18821 ISSN 0216-0455 (Print), ISSN 2527-3825 (Online) Tersedia online di https://jurnal.ugm.ac.id/agritech/

\title{
Skrining Lactobacillus plantarum Penghasil Asam Laktat untuk Fermentasi Mocaf
}

\author{
Screening of Lactobacillus plantarum Producing Lactic Acid for Mocaf Fermentation \\ Zulafa Noor $^{1 *}$, Muhammad Nur Cahyanto ${ }^{2}$, Retno Indrati ${ }^{2}$, S. Sardjono \\ ${ }^{1}$ Sekolah Tinggi Teknologi Nasional, Jl. Babarsari Caturtunggal, Depok, Sleman, Yogyakarta 55281, Indonesia \\ ${ }^{2}$ Departemen Teknologi Pangan dan Hasil Pertanian, Fakultas Teknologi Pertanian, Universitas Gadjah Mada, \\ Jl. Flora No. 1, Bulaksumur, Yogyakarta 55281, Indonesia \\ Email: zulafa.noor@yahoo.com
}

Submisi: 31 Desember 2015; Penerimaan: 4 Mei 2017

\begin{abstract}
ABSTRAK
Penelitian ini bertujuan untuk memilih isolat Lactobacillus plantarum terbaik dari 6 (enam) macam isolat lokal yang diperoleh dari koleksi kultur yang berasal dari makanan tradisional. Pemilihan isolat didasarkan pada kecepatan pertumbuhan, jumlah sel, perubahan $\mathrm{pH}$ dan produksi asam laktat selama pertumbuhan pada media MRS-broth pada suhu $37{ }^{\circ} \mathrm{C}$ selama 24 jam. Hasil penelitian menunjukkan bahwa kecepatan pertumbuhan setiap isolat bervariasi, yang diukur dari lamanya fase log, yaitu berkisar antara 8-20 jam. Ini memperlihatkan bahwa beberapa isolat cukup cepat menuju fase stasioner dan beberapa lagi cukup lambat. Jumlah sel berkisar antara 8,81-9,74 log CFU/mL, sedangkan pH pada awal pertumbuhan sekitar 5,2-5,8, dan pada akhir pertumbuhan 3,4-3,7. Produksi asam laktat pada akhir pertumbuhan (24 jam) adalah 0,76-0,98\%. Dari hasil tersebut isolat L. plantarum UA3 merupakan isolat terbaik dengan fase pertumbuhan log yang tercepat ( 8 jam), jumlah sel tertinggi $(9,74$ log CFU/mL), dan menghasilkan asam laktat paling tinggi $(0,92 \%)$ pada inkubasi selama 14 jam dalam media MRS-broth suhu $37{ }^{\circ} \mathrm{C}$. Aplikasi dari isolat terpilih L.plantarum UA3 dalam fermentasi substrat padat menggunakan media kasava parut menghasilkan asam laktat sebesar 0,92\% setelah fermentasi selama 60 jam, dengan jumlah sel 9,54 logCFU/mL.
\end{abstract}

Kata kunci: Kasava parut; asam laktat; Lactobacillus plantarum; fermentasi substrat padat

\begin{abstract}
This study was aimed to select the best isolates of Lactobacillus plantarum from 6 (six) of local isolates obtained from culture collections isolated from traditional foods. Selection of isolates was based on the growth rate, the number of cells, changes in $\mathrm{pH}$ and lactic acid production during cell growth on the MRS-broth at $37^{\circ} \mathrm{C}$ for 24 hours. The results showed that the growth rate of each isolate varied, as measured by the length of the log phase, ranging from 8-20 h. It showed that some isolates quite fast towards a stationary phase and some quite slow. The number of cell ranged from 8.81 to $9.74 \log \mathrm{CFU} / \mathrm{mL}$, while the $\mathrm{pH}$ at the beginning of cell growth from 5.2 to 5.8 , and at the end of growth from 3.4 to 3.7. Lactic acid production by the end of the growth $(24 \mathrm{~h})$ is 0.76 to $0.98 \%$. The results showed isolate of $L$. plantarum UA3 was best having the fastest growth rate ( $8 \mathrm{~h}$ of $\log$ phase), the highest cell number $(9.74 \log \mathrm{CFU} /$ $\mathrm{mL})$, and the highest lactic acid produced $(0.92 \%)$ for $14 \mathrm{~h}$ incubation on MRS-broth at $37^{\circ} \mathrm{C}$. Application of selected isolate of $L$. plantarum $\mathrm{UA} 3$ on solid substrate fermentation using media grated cassava yield in $0.92 \%$ lactic acid after fermentation for $60 \mathrm{~h}$, with a cell number of $9.54 \log \mathrm{CFU} / \mathrm{mL}$.
\end{abstract}

Keywords: Grated cassava; lactic acid; Lactobacillus plantarum; solid substrate fermentation 


\section{PENDAHULUAN}

Lactobacillus plantarum merupakan salah satu species dari bakteri asam laktat (BAL). Bakteri ini merupakan bakteri penghasil asam laktat dan banyak digunakan untuk fermentasi mocaf. L. plantarum bersifat amilolitik (Reddy dkk., 2008) yang secara langsung akan merubah pati menjadi asam laktat. L. plantarum dapat digunakan sebagai starter pada proses fermentasi yang berperan dalam peningkatan produksi asam laktat (Reddy dkk., 2003). Beberapa strain dari L. plantarum telah diisolasi dari produk kasava terfermentasi garri yaitu makanan tradisional Afrika, antara lain L. manihotivorans OND32T (Guyot dkk., 2001). Sedangkan Lacerda dkk. (2005) menemukan L. plantarum dan L. fermentum yang dominan pada fermentasi di dua pabrik di Brazil. Anike dan Okafor (2008) menunjukkan bahwa L. plantarum dan Lactobacillus sp. tumbuh dominan pada pembuatan garri. Di Indonesia, beberapa penelitian telah dilakukan antara lain dari growol yang menunjukkan jenis L. plantarum-pentosus dan L. plantarum tumbuh pada makanan tradisional tersebut (Rahayu, 1996; Rahayu dkk., 1996). Putri dkk. (2011) melaporkan bahwa dalam fermentasi growol dapat diisolasi tiga macam isolat L. plantarum dengan strain yang berbeda. Berdasarkan hasil peneltian tersebut perlu dilakukan skrining L. plantarum dengan beberapa strain yang berbeda untuk memperoleh isolat lokal yang terbaik.

Modified cassava flour (Mocaf) merupakan modifikasi tepung kasava dengan cara fermentasi pada proses pembuatannya (Kurniati, 2012). Pada umumnya preparasi mocaf dilakukan dengan cara perendaman atau Liquit Substrate Fermentation (LSF), cara ini memerlukan waktu 20-30 hari, dan pertumbuhan mikrobianya tidak terkontrol sehingga menghasilkan produk yang kualitasnya tidak seragam, kurang praktis karena tidak siap pakai (Sobowale dkk., 2007; Hodidjah, 2012). Fermentasi mocaf melalui fermentasi substrat padat atau Solid Substrate Fermentation (SSF), lebih menguntungkan karena bisa menghemat energi untuk pengeringan, hemat air dan hemat waktu; fermentasi bisa terkendali dan produk seragam (Widiatmi, 2013). Menurut Arisanti (2012), fermentasi mocaf dengan SSF pada media padat kasava parut menunjukkan bahwa bakteri liar bisa terdesak setelah 6 jam fermentasi. Hal ini mengindikasikan bahwa fermentasi mocaf bisa dilakukan dengan SSF. Namun ketersediaan starter perlu dipikirkan karena selama ini starter powder untuk SSF mocaf belum tersedia di pasaran. Apalagi saat ini belum tersedia starter powder kultur tunggal BAL yang digunakan secara langsung oleh industri pengolahan kasava. Starter powder dengan kulltur tunggal menyebabkan fermentasi bisa dikendalikan (Carminati dkk., 2010). Oleh karena itu pemilihan isolat lokal L. plantarum penghasil asam laktat tinggi dan dapat tumbuh pada media padat kasava parut, menjadi perhatian khusus yang dapat dikembangkan untuk pembuatan starter powder kultur tunggal.

Tujuan penelitian adalah memilih strain L. plantarum terbaik berdasarkan laju pertumbuhan yang cepat dan jumlah sel yang tinggi pada saat memasuki fase stasioner, perubahan $\mathrm{pH}$ selama pertumbuhan dan produksi asam laktat yang tinggi. Isolat yang terpilih di aplikasikan pada media padat kasava parut.

\section{METODE PENELITIAN}

\section{Bahan Penelitian}

Isolat Lactobacillus plantarum diperoleh dari Food and Nutrition Culture Colection, Pusat Studi Pangan dan Gizi, Universitas Gadjah Mada, Yogyakarta. Strain yang digunakan ada 6 (enam) macam, yaitu: L. plantarum T3, L. plantarum T13, L. plantarum T32, L. plantarum UA3, L. plantarum AA2, dan L. plantarum AA11. Media untuk pertumbuhan BAL adalah MRS-agar, MRS-broth, dan kasava parut (digunakan untuk media pertumbuhan isolat L.plantarum terpilih). Kasava parut yang digunakan berasal dari kasava varietas Meni umur 8-10 bulan.

\section{Skrining Pertumbuhan Sel L. plantarum pada Media MRS-broth}

Penelitian ini dilakukan dengan menginokulasikan tiap isolat bakteri L. plantarum sebanyak $1 \mathrm{~mL}$ suspensi sel (umur 24 jam dalam medium MRS-broth) ke dalam $100 \mathrm{~mL}$ media MRS-broth, kemudian diinkubasi pada suhu $37^{\circ} \mathrm{C}$ selama 24 jam. Setiap 2 jam dilakukan pengamatan, yang meliputi pengamatan: (a) jumlah sel BAL (menggunakan metode pour plate menggunakan media MRS-agar sesuai metode AOAC (Anonim, 1995), (b) pH media (menggunakan $\mathrm{pH}$ meter, SCHOOT Instrument) dan (c) kadar asam laktat (dengan mengukur total asam tertitrasi sesuai metode Tetchi, 2012).

\section{Fermentasi Kasava Parut Menggunakan L. plantarum Terpilih}

Kasava varietas Meni direndam dalam air mendidih selama 5 menit, kemudian ditiriskan dan diparut (Jawa disawut). Diambil 100 g parutan kasava dan tambahkan 0,1 $\mathrm{mL}$ starter L. plantarum terpilih (umur 24 jam dalam medium MRS-broth). Kemudian diaduk dan diinkubasi selama 60 jam pada suhu kamar $\left( \pm 28^{\circ} \mathrm{C}\right)$. Tiap 6 jam sekali (sampai dengan 48 jam) diamati parameter yang meliputi jumlah sel, $\mathrm{pH}$, dan kadar asam laktat. Kemudian pada inkubasi 48 jam sampai 64 jam pengamatan dilakukan tiap 2 jam sekali. 


\section{Analisis Data}

Data yang dihasilkan dihitung standard deviasi dan diuji beda nyata dengan uji Duncan's Multiple Range Test (pada tingkat kepercayaan $\alpha=5 \%$ ).

\section{HASIL DAN PEMBAHASAN}

Skrining pertumbuhan sel L. plantarum pada media MRS Broth. Pada tahap ini dilakukan dengan mengamati pertumbuhan L.plantarum isolat lokal dari 6 macam strain masing-masing dalam media cair (MRS-Broth). Pertumbuhan sel dalam media cair dipaparkan dalam Gambar 1.

Dari 6 (enam) macam isolat L.plantarum yang dipakai diperoleh berbagai macam fase log, fase stasioner, maupun jumlah sel yang tumbuh (Gambar 1). Secara umum fase log terjadi selama 8 jam (0-8 jam inkubasi), kecuali pada isolat L. plantrum T32 (0-10 jam inkubasi) dan T13 (0-20 jam inkubasi) yang fase log-nya lebih lama. Isolat $L$. plantrum UA3 selain cepat fase $\log (0-8$ jam inkubasi) dan fase stasioner-nya (8-17 jam inkubasi), jumlah sel isolat tersebut juga paling tinggi, yaitu 9,74 $\log \mathrm{CFU} / \mathrm{mL}$. L. plantarum AA2, L. plantarum AA11, L. plantarum T13 menunjukkan pertumbuhan stasioner yang masih tetap berlangsung sampai akhir inkubasi (24 jam). Kecepatan pertumbuhan L. plantarum jika dibandingkan dengan bakteri lain lebih tinggi (Kurtman dkk., 2009). Bakteri tersebut dapat tumbuh baik pada substrat yang kaya akan nutrisi seperti Mann Rogosa Sharpe Broth (MRS-broth).

Pertumbuhan dan viabilitas sel yang berbeda akan menyebabkan $\mathrm{pH}$ yang dihasilkan juga berbeda, karena metabolit yang dihasilkan juga berbeda. Perubahan $\mathrm{pH}$ selama pertumbuhan L. plantarum dari 6 (enam) isolat lokal dipaparkan pada Gambar 2. Terlihat bahwa perubahan $\mathrm{pH}$ untuk semua isolat hampir sama, yaitu pada jam ke 0 (awal pertumbuhan sel) $\mathrm{pH}$ antara 5,15-5,8 dan setelah 24 jam pertumbuhan sel $\mathrm{pH}$ antara 3,40-3,65. Produksi asam laktat berkontribusi terhadap penurunan $\mathrm{pH}$ dan dapat menghambat

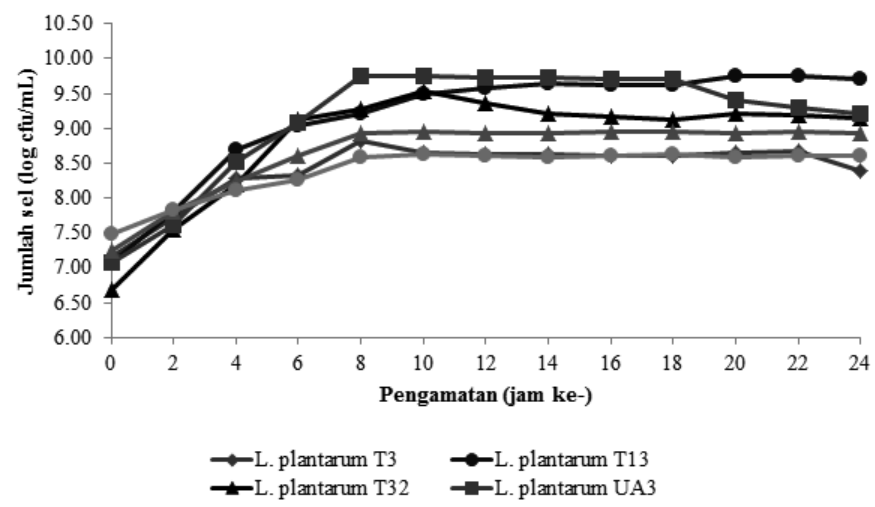

Gambar 1. Pertumbuhan sel Lactobacillus plantarum pada media MRS broth

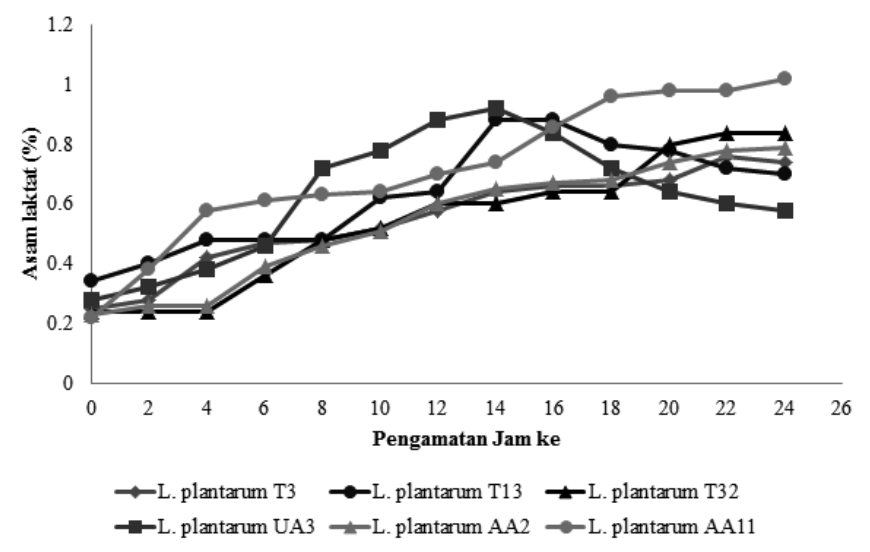

Gambar 2. pH Lactobacillus plantarum pada media MRS broth

pertumbuhan bakteri lain selain bakteri asam laktat. Bakteri asam laktat juga menghasilkan metabolit lain yang berfungsi sebagai anti mikrobia seperti asam asetat, hidrogen peroksida, dan bakteriosin (Phumkhachorn dan Rattanachaikun, 2010). Kemampuan penghambatan terhadap bakteri selain bakteri asam laktat meningkat sejalan dengan penurunan $\mathrm{pH}$. Penurunan $\mathrm{pH}$ terjadi karena adanya pembentukan metabolit berupa asam. Semakin lama waktu inkubasi maka semakin banyak metabolit yang terbentuk sehingga $\mathrm{pH}$ akan menurun.

Asam organik merupakan produk akhir dari metabolisme karbohidrat oleh bakteri asam laktat. Asam laktat merupakan produk utama pada fermentasi karbohidrat oleh bakteri asam laktat (Dalie dkk., 2010). Produk asam laktat selama pertumbuhan sel L. plantarum dari 6 (enam) isolat local dapat dilihat pada Gambar 3.

Pada Gambar 3 terlihat bahwa kenaikan kadar asam laktat terjadi secara perlahan-lahan selama pertumbuhan sel. Pada awal inkubasi kadar asam laktat berkisar antara 0,20 $0,35 \%$ yang menunjukkan belum diproduksinya asam laktat oleh bakteri L. plantarum. Pada masing-masing isolat yang digunakan, terdapat perbedaan peningkatan kadar asam laktat.

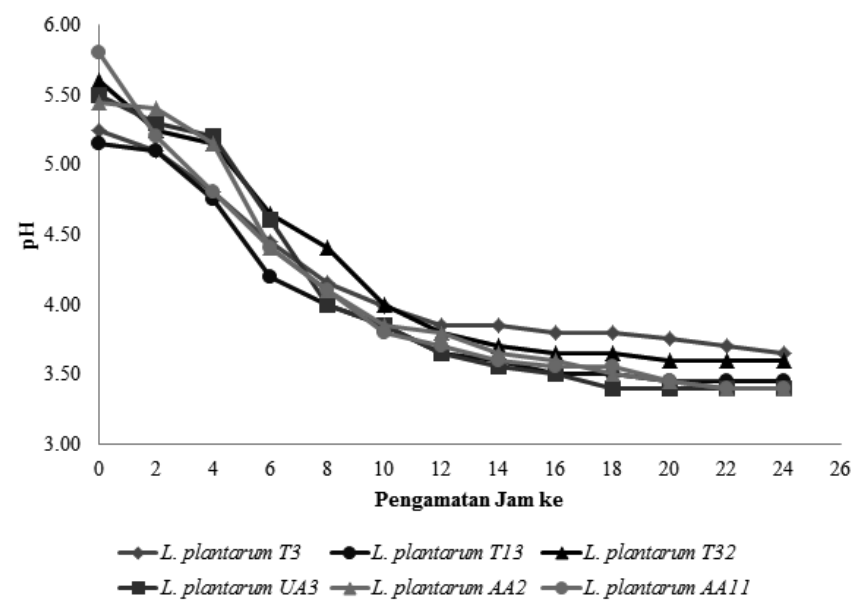

Gambar 3. Asam laktat Lactobacillus plantarum pada media MRS broth 
Tabel 1. Populasi sel, perubahan $\mathrm{pH}$, dan produksi asam laktat dari berbagai isolat L. plantarum lokal yang ditumbuhkan dalam medium MRS-broth selama 24 jam pada suhu $37^{\circ} \mathrm{C}$

\begin{tabular}{|c|c|c|c|c|c|c|}
\hline \multirow{2}{*}{ Isolat } & \multirow{2}{*}{$\begin{array}{l}\text { Fase log (jam } \\
\text { inkubasi) }\end{array}$} & \multirow{2}{*}{$\begin{array}{l}\text { Fase stasioner (jam } \\
\text { inkubasi) }\end{array}$} & \multirow{2}{*}{$\begin{array}{l}\text { Jumlah sel (log } \\
\text { CFU/mL) }\end{array}$} & \multicolumn{2}{|c|}{$\mathrm{pH}$} & \multirow{2}{*}{$\begin{array}{l}\text { Asam laktat }(\%) \\
\text { (pada inkubasi jam) }\end{array}$} \\
\hline & & & & $\begin{array}{c}\text { Awal } \\
\text { fermentasi }\end{array}$ & $\begin{array}{c}\text { Akhir } \\
\text { fermentasi }\end{array}$ & \\
\hline UA3 & $0-8$ & $8-17$ & $9,74 \pm 0,01^{\text {a }}$ & $5,50 \pm 0,03^{c}$ & $3,40 \pm 0,01^{b}$ & $0,92 \pm 0,02^{a b}(\mathrm{j} \mathrm{14})$ \\
\hline $\mathrm{T} 3$ & $0-8$ & $8-22$ & $8,81 \pm 0,01^{\mathrm{d}}$ & $5,25 \pm 0,05^{d}$ & $3,65 \pm 0,05^{\mathrm{a}}$ & $0,76 \pm 0,14^{\mathrm{c}}(\mathrm{j} 22)$ \\
\hline AA11 & $0-8$ & $8-24$ & $8,59 \pm 0,03^{\mathrm{e}}$ & $5,80 \pm 0,04^{a}$ & $3,40 \pm 0,01^{\mathrm{b}}$ & $0,98 \pm 0,01^{\mathrm{a}}(\mathrm{j} 20)$ \\
\hline AA2 & $0-8$ & $8-24$ & $8,94 \pm 0,01^{\mathrm{c}}$ & $5,45 \pm 0,04^{\mathrm{c}}$ & $3,40 \pm 0,03^{b}$ & $0,79 \pm 0,01$ bc $(\mathrm{j} 24)$ \\
\hline $\mathrm{T} 32$ & $0-10$ & $10-24$ & $9,53 \pm 0,01^{\mathrm{b}}$ & $5,60 \pm 0,03^{b}$ & $3,66 \pm 0,01^{a}$ & $0,84 \pm 0,02^{\mathrm{bc}}(\mathrm{j} 22)$ \\
\hline $\mathrm{T} 13$ & $0-20$ & $20-24$ & $9,74 \pm 0,14^{a}$ & $5,15 \pm 0,05^{\mathrm{e}}$ & $3,45 \pm 0,05^{b}$ & $0,88 \pm 0,10^{\mathrm{a}-\mathrm{c}}(\mathrm{j} 14)$ \\
\hline
\end{tabular}

Keterangan: Huruf yang berbeda pada kolom yang sama menunjukkan adanya beda nyata berdasarkan uji Duncan's Multiple RangeTest pada taraf nyata 5 \%.

Peningkatan kadar asam laktat tertinggi terjadi pada kisaran waktu inkubasi 14-24 jam dengan produksi asam laktat berkisar antara 0,76-0,98\%. Produksi asam laktat tercepat terjadi setelah 14 jam inkubasi pada isolat L. plantarum UA3 dengan produksi asam laktat sebanyak 0,92\% dan $L$. plantarum T13 dengan produksi asam laktat sebanyak 0,88\%. Agak sedikit lebih lambat, L. plantarum AA11 menghasilkan asam laktat sebanyak 0,98\% setelah inkubasi selama 20 jam. Menurut Brashears dan Carminati (2010) sel yang mampu tumbuh pada $\mathrm{pH}$ antara 5,0-6,5 akan terus menghasilkan asam setelah mencapai fase stasioner. Bakteri asam laktat mampu bertahan hidup pada $\mathrm{pH}$ rendah (Papagianni, 2012).

Rangkuman hasil dari data terbaik tiap-tiap isolat dapat dilihat pada Tabel 1. Dilihat dari jumlah sel, kecepatan pertumbuhan sel dihitung dari kecepatan tercapainya fase stasioner, dan produksi asam laktat, maka isolat $L$.plantarum UA3 merupakan isolat yang terpilih untuk digunakan pada fermentasi mocaf yang cepat (kemungkinan akan lebih cepat dari proses fermentasi mocaf kultur rendam).

\section{Aplikasi L. plantarum Terpilih untuk Fermentasi Mocaf}

Isolat terbaik (L. plantarum UA3) di aplikasikan pada fermentasi mocaf kasava parut segar dan diamati jumlah sel, perubahan $\mathrm{pH}$, dan hasil produksi asam laktat selama fermentasi berjalan. Aplikasi ini diharapkan dapat mempercepat proses asidifikasi, mengendalikan proses fermentasi, menghasilkan produk yang lebih baik daripada fermentasi tanpa penambahan starter, dan mengurangi resiko yang terkait dengan higienitas (Huch dkk., 2008). Hasil pengujian pada tahap ini dapat dilihat pada Tabel 2. Aplikasi L. plantarum UA3 pada kasava parut segar, menunjukkan pertumbuhan bakteri asam laktat sebesar $10^{9} \mathrm{CFU} / \mathrm{g}$ tercapai setelah fermentasi berjalan $60 \mathrm{jam}$, dan produksi asam laktat sebesar $0,92 \%$. Setelah itu jumlah sel dan produk asam laktat mulai menurun.

Menurut Arisanti (2012), semakin lama waktu fermentasi, jumlah bakteri selain BAL semakin menurun sejalan dengan pertumbuhan L. plantarum subsp

Tabel 2. Pertumbuhan L. plantarum UA3 pada media kasava parut

\begin{tabular}{cccc}
\hline $\begin{array}{c}\text { Fermentasi } \\
\text { (jam) }\end{array}$ & $\begin{array}{c}\text { Populasi sel } \\
\text { BAL(CFU/g) }\end{array}$ & pH & $\begin{array}{c}\text { Asam laktat } \\
(\%)\end{array}$ \\
\hline 0 & $7,4 \times 10^{7}$ & 6,3 & $0,12 \pm 0,04^{\mathrm{f}}$ \\
6 & $8,8 \times 10^{7}$ & 6,1 & $0,27 \pm 0,05^{\mathrm{e}}$ \\
12 & $1,4 \times 10^{7}$ & 5,9 & $0,40 \pm 0,15^{\mathrm{d}}$ \\
18 & $2,7 \times 10^{7}$ & 5,3 & $0,44 \pm 0,09^{\mathrm{cd}}$ \\
24 & $1,0 \times 10^{7}$ & 4,8 & $0,45 \pm 0,05^{\mathrm{cd}}$ \\
30 & $2,3 \times 10^{7}$ & 4,7 & $0,50 \pm 0,08^{\mathrm{cd}}$ \\
36 & $3,6 \times 10^{7}$ & 4,6 & $0,54 \pm 0,04^{\mathrm{c}}$ \\
42 & $5,4 \times 10^{7}$ & 4,5 & $0,78 \pm 0,06^{\mathrm{b}}$ \\
48 & $9,1 \times 10^{7}$ & 4,4 & $0,79 \pm 0,09^{\mathrm{b}}$ \\
50 & $3,6 \times 10^{8}$ & 4,3 & $0,80 \pm 0,05^{\mathrm{ab}}$ \\
52 & $4,7 \times 10^{8}$ & 4,2 & $0,83 \pm 0,10^{\mathrm{ab}}$ \\
54 & $5,3 \times 10^{8}$ & 4,1 & $0,88 \pm 0,06^{\mathrm{ab}}$ \\
56 & $6,2 \times 10^{8}$ & 4,1 & $0,89 \pm 0,02^{\mathrm{ab}}$ \\
58 & $7,7 \times 10^{9}$ & 4,0 & $0,89 \pm 0,01^{\mathrm{ab}}$ \\
60 & $8,3 \times 10^{9}$ & 4,0 & $0,92 \pm 0,02^{\mathrm{a}}$ \\
62 & $4,1 \times 10^{8}$ & 3,8 & $0,83 \pm 0,02^{\mathrm{ab}}$ \\
64 & $1,3 \times 10^{8}$ & 3,8 & $0,80 \pm 0,04^{\mathrm{ab}}$ \\
\hline & & &
\end{tabular}

Keterangan: Huruf yang berbeda pada kolom yang sama menunjukkan adanya beda nyata berdasarkan uji Duncan's Multiple Range Test pada taraf nyata $5 \%$ 
Argentorarensis. Selama fermentasi berlangsung jumlah sel bakteri semakin meningkat dan mampu menggeser jumlah bakteri lain selain BAL. L. plantarum mempunyai kemampuan menghasilkan asam dengan cepat dan lebih banyak dibandingkan dengan L. brevis, L. fermentum, dan $L$. acidophilus.

Produksi asam laktat oleh BAL berkontribusi terhadap penurunan $\mathrm{pH}$ dan penghambatan bakteri selain BAL. Hasil penelitian yang dilakukan oleh Gunaratne (2007), menunjukkan terjadinya penghambatan bakteri gram negatif pada gandum dan maizena yang difermentasi menggunakan asam laktat. Bakteri asam laktat juga menghasilkan metabolit lain yang berfungsi sebagai anti mikrobia seperti asam asetat, hidrogen peroksida, dan bakteriosin (Phumkhachorn dan Rattanachaikunsopon, 2010). Kemampuan menghambat bakteri lain selain BAL meningkat sejalan dengan penurunan $\mathrm{pH}$. Hasil penelitian ini menunjukkan bahwa $\mathrm{pH}$ pada awal fermentasi adalah 6,1-6,3. Penurunan $\mathrm{pH}$ terjadi karena ada pembentukan metabolit yang berupa asam. Semakin lama fermentasi berlangsung maka semakin banyak metabolit yang terbentuk. Akumulasi metabolit ini dapat menghambat pertumbuhan bakteri lain selain BAL selama fermentasi. Dari penelitian ini, asam laktat tertinggi sebesar $0,92 \%$ diperoleh setelah fermentasi berlangsung selama 60 jam.

\section{KESIMPULAN}

L. plantarum UA3 merupakan isolat terbaik dari 6 (enam) macam isolat lokal L. plantarum yang diseleksi. Bakteri tersebut mempunyai pertumbuhan yang cepat (fase log selama 8 jam inkubasi) dan jumlah sel tertinggi (9,74 log $\mathrm{CFU} / \mathrm{mL}$ ). Selain itu L. plantarum UA3 mempunyai potensi sebagai bakteri penghasil asam laktat yang tinggi ( $0,92 \%$ pada inkubasi 14 jam pada medium MRS-broth). Kemampuan menghasilkan asam laktat tinggi tetap ditunjukkan walaupun ditumbuhkan dalam media padat kasava parut $(0,92 \%$ pada inkubasi 60 jam). Pada medium kasava parut tersebut, bakteri L. plantarum UA3 tetap menunjukkan pertumbuhan yang lebat (9,54 $\log \mathrm{CFU} / \mathrm{mL}$ pada inkubasi 60 jam). Sehingga $L$. plantarum UA3 mempunyai potensi untuk dikembangkan sebagai starter powder kultur tunggal.

\section{UCAPAN TERIMA KASIH}

Penulis mengucapkan terima kasih kepada Direktorat Jendral Pendidikan Tinggi yang telah memberikan dana melalui program Penelitian Disertasi Doktor tahun 2014.

\section{DAFTAR PUSTAKA}

Anike N. dan Okafor, N. (2008). Secretion of methionine by microorganism assosiated with cassava fermentation.
African Journal of Food, Agriculture, Nutrition and Development 8: 77-90.

Anonim (1995). Bacterial Analytical Manual $8^{\text {th }}$ Ed. AOAC International. Gaitherburg.

Arisanti, D. (2012). Viabilitas Bakteri Asam Laktat Selama Penyiapan dan Penyimpanan Ragi Mocaf serta Aplikasinya pada Fermentasi Ubi Kayu Segar. Tesis. Fakultas Teknologi Pertanian. Universitas Gadjah Mada, Yogyakarta.

Brashears, M.M. dan Carminati D. (2010). Survival during frozen and subsequent refrigerated storage of Lactobacillus acidophillus cells as influenced by the growth phase. Journal of Dairy Science 78: 2326-2335.

Carminati, D., Giraffa, G., Quiberoni, A., Binetti, A., Suarez, V. dan Reinheimer, J. (2010). Advances and trends in starter cultures for dairy fermentation. Ed. F. Mozzi, R. Raya, and G. M. Vignolo. Dalam: Biotechnology of Lactic Bacteria. 177-192. Willey-Blackwell, Iowa.

Dalie, D.K.D., Deschamps, A.M. dan Richard-Forget, F. (2010). Lactic acid bacteria potential for control of mould growth and mycotoxin. Food Control 21: 370 380 .

Gunaratne, A. dan Corke, H. (2007). Influence of prior acid treatment on acetylation of wheat, potato, and maize starch. Food Chemistry 105: 917-925.

Guyot, J.P. dan Morlon-Guyot, J. (2001). Effect of different cultivation condition on Lactobacillus manihotivorans OND32T, an amylolytic lactobacillus isolated from cassava sour starch. International Journal of Food Microbiologi 67: 217-225.

Hodidjah, S. (2012). Cara Membuat Tepung Mocaf atau Motekap. Badan Pelaksana Penyuluhan Pertanian Perikanan dan Kehutanan (BP4K) Kabupaten Bogor. www.bp4k.bogorkab.go.id. [2 Mei 2012].

Huch, M., Hanak, A., Specht, I., Dortu, C.M., Thonart, P., Mbugua, S., Holzapfel, C. dan Franz, C.M.A.P. (2008). Use of Lactobacillus strain to start cassava fermentations for Garri production. International Journal of Food Microbiology 128: 258-267.

Kurniati, L.L., Aida, N., Gunawan, S. dan Widjaja, T. (2012). Pembuatan mocaf (modified cassava flour) dengan proses fermentasi menggunakan Lactobacillus plantarum, Saccharomyces cerevisae dan Rhizopus oryzae. Jurnal Teknik POMITS 1(1): 1-6.

Kurtman, L., Charlote, U.C., Jeins, R. dan Leis, H.S. (2009). Storage stabillity of freeze-dried Lactobacillus acidophillus (La-5) in relation to water activity and 
precence of oxygen and ascorbate. Cryobiology 58: $175-180$.

Lacerda, I.C.A., Miranda, R.L., Borelli, B.M., Nunes, A.C., Nardi, R.M.D., Lachance, M.A. dan Rosa, C.A. (2005). Lactic acid bacteria and yeasts assosiated with spontaneous fermentations during the production of sour cassava starch in Brazil. International Journal of Food Microbiology 105: 213-219.

Papagianni, M. (2012). Metabolyc Engineering of lactic acid bacteria for the production on industrially important compound. Computational and Structural Biotechnology Journal 3(4): 1-8.

Phumkhachorn, P. dan Rattanachaikunsopon, P. (2010). Lactic acid bacteria: their antimicrobial compounds and their uses in food production. Annals of Biological Research 1(4): 218-228.

Putri, W.D.R., Haryadi, Marseno, D.W. dan Cahyanto, M.N. (2011). Effect of biodegradation by lactic acid bacteria on physical properties of cassava starch. International Food Research Journal 18(3): 1149-1154.

Rahayu, E.S. (1996). Lactic acid bacteria in fermented food of indonesia origin. Agritech 23(2): 75-84.
Rahayu, E.S., Djaffar, T.F., Wibowo, D. dan Sudarmadji, S. (1996). Lactic acid bacteria from indigenous fermented food and their antimicrobial activity. Journal Indonesian Food and Nutrition Progress 3(2): 21-27.

Reddy, G.M., Altaf, B.J. Naveena, M. Venkateshwar, E. dan Kumar, V. (2008). Amylolytic bacterial lactic acid fermentation, a review. Biotechnology Advances 26: 22-34.

Sobowale, A.O., Olurin, T.O. dan Oyewole, O.B. (2007). Effect of lactid acid bacteria starter culture fermentation of cassava on chemical and sensory characteristic of "fufu" flour. African Journal of Biotechnology 6(16): 1954-1958.

Tetchi, F.A. (2012). Effect of cassava variety and fermentation time on biochemical and microbiological characteristics of raw artisanal starter for "attieke" production. Innovative Romanian Food Biotechnology 10: 40-47.

Widiatmi, N. (2013). Profil Fermentasi Hancuran Kasava Menggunakan Starter Basah Bakteri Lactobacillus Plantarum UA3 dengan Bahan Pembawa Hancuran Kasava. Tesis. Fakultas Teknologi Pertanian. Universitas Gadjah Mada, Yogyakarta. 